\title{
Cyclic Tetrapyrrolic Photosensitisers from the leaves of Phaeanthus ophthalmicus
}

\author{
Pei Jean Tan ${ }^{1}$, Cheng Yi Ong ${ }^{1}$, Asma Danial ${ }^{2}$, Hirzun Mohd Yusof ${ }^{2}$, Bee Keat Neoh ${ }^{2}$ and Hong Boon Lee ${ }^{*}$
}

\begin{abstract}
Background: Twenty-seven extracts from 26 plants were identified as photo-cytotoxic in the course of our bioassay guided screening program for photosensitisers from 128 extracts prepared from 64 terrestrial plants in two different collection sites in Malaysia - Royal Belum Forest Reserve in the State of Perak and Gunung Nuang in the State of Selangor. One of the photo-cytotoxic extracts from the leaves of Phaeanthus ophtalmicus was further investigated.
\end{abstract}

Results: The ethanolic extract of the leaves from Phaeanthus ophtalmicus was able to reduce the in vitro viability of leukaemic HL60 cells to < 50\% when exposed to $9.6 \mathrm{~J} / \mathrm{cm}^{2}$ of a broad spectrum light at a concentration of $20 \mu \mathrm{g} /$ $\mathrm{mL}$. Dereplication of the photo-cytotoxic fractions from P. ophthalmicus extracts based on TLC Rf values and HPLC co-injection of reference tetrapyrrolic compounds enabled quick identification of known photosensitisers, pheophorbide- $a$, pheophorbide- $a$ methyl ester, $13^{2}$-hydroxypheophorbide- $a$ methyl ester, pheophytin- $a$ and $15^{1}$ hydroxypurpurin 7-lactone dimethyl ester. In addition, compound $\mathbf{1}$ which was not previously isolated as a natural product was also identified as 7-formyl-15'-hydroxypurpurin-7-lactone methyl ester using standard spectroscopic techniques.

Conclusions: Our results suggest that the main photosensitisers in plants are based on the cyclic tetrapyrrole structure and photosensitisers with other structures, if present, are present in very minor amounts or are not as active as those with the cyclic tetrapyrrole structure.

\section{Background}

Malaysia is well-known as one of the mega-biodiversity country in the world. Among the places that Malaysia has restricted their access as forest reserves are Royal Belum Forest Reserve and Gunung Nuang at the Langat Forest Reserve. The Royal Belum Forest Reserve which is estimated to be 130 million years old [1], covers an area of $3000 \mathrm{~km}^{2}$ and is home to numerous plant species as well as over 270 species of birds and 100 species of mammals [2]. Gunung Nuang or Mount Nuang with its highest point at $1495 \mathrm{~m}$ above sea level [3] is situated in the Langat Basin which covers an estimated area of $2937 \mathrm{~km}^{2}$ and is covered in dipterocarp forests. In our search for potential novel photosensitisers from the under-explored natural habitats of Malaysia, 64 plant samples were collected from Gunung Nuang and Royal

\footnotetext{
* Correspondence: hongboon.lee@carif.com.my

${ }^{1}$ Cancer Research Initiatives Foundation (CARIF), Sime Darby Medical

Centre,1, Jalan SS12/1A, 47500 Subang Jaya, Selangor Darul Ehsan, Malaysia Full list of author information is available at the end of the article
}

Belum Forest Reserve. Photosensitisers are compounds employed in photodynamic therapy to generate reactive oxygen species in the presence of light and molecular oxygen for removing abnormal cells and tissues in the treatment of some forms of cancer and other non-oncological diseases [4].

This paper describes the sourcing and testing of 128 plant extracts using a MTT-based photocytotoxicity assay, and bioassay guided fractionation of one of the active samples Phaeanthus ophthalmicus, identification of known photosensitisers in the extracts by comparing with in-house standards and isolation and elucidation of one new photosensitiser.

\section{Results and Discussion \\ Screening result}

A total of 128 extracts were obtained from the 64 plants collected in July 2007. These plant species are from 39 different families (Table 1). A sample is considered photo-cytotoxic if it causes the cell culture to be $<50 \%$ 
Table 1 Plant extracts screened for photo-cytotoxicity in HL60 cells at $20 \mu \mathrm{g} / \mathrm{ml}$

\begin{tabular}{|c|c|c|c|c|}
\hline Family & Scientific Name & Plant parts & Location & Activity* \\
\hline \multirow[t]{5}{*}{ Acanthaceae } & Filetia hirta & Bark & Gunung Nuang & - \\
\hline & & Leaves & & + \\
\hline & & Root & & - \\
\hline & Justicia ptychostoma & Leaves & Belum & + \\
\hline & & Bark & & - \\
\hline \multirow[t]{7}{*}{ Annonaceae } & Anaxagorea javanica & Leaves & Belum & + \\
\hline & & Bark & & + \\
\hline & Fissistigma sp. & Leaves & Belum & + \\
\hline & Popowia tomentosa & Leaves & Belum & - \\
\hline & & Bark & & - \\
\hline & Phaeanthus ophthalamicus & Leaves & Belum & + \\
\hline & & Bark & & - \\
\hline Araceae & Epipremnum giganteum & Bark & Gunung Nuang & - \\
\hline \multirow[t]{3}{*}{ Arecaceae } & Pinanga sp. & Bark & Gunung Nuang & - \\
\hline & & Fruit & & - \\
\hline & & Leaves & & + \\
\hline \multirow[t]{2}{*}{ Aristolochiaceae } & Thottea grandiflora & Leaves & Belum & + \\
\hline & & Bark & & - \\
\hline \multirow[t]{3}{*}{ Asteraceae } & Elephantopus mollis & Bark & Gunung Nuang & - \\
\hline & & Leaves & & + \\
\hline & & Root & & - \\
\hline \multirow[t]{3}{*}{ Burseraceae } & Canarium pilosum & Leaves & Belum & + \\
\hline & & Bark & & - \\
\hline & Canarium sp. & Fruit & Belum & - \\
\hline Chloranthaceae & Chloranthus officinalis & Leaves & Belum & - \\
\hline \multirow[t]{5}{*}{ Clusiaceae } & Calophyllum sp. & Bark & Gunung Nuang & - \\
\hline & Garcinia malaccensis & Bark & Gunung Nuang & - \\
\hline & & Root & & ++ \\
\hline & Garcinia parvifolia & Leaves & Belum & + \\
\hline & & Bark & & - \\
\hline \multirow[t]{2}{*}{ Commelinaceae } & Pollia thyrsiflora & Bark & Gunung Nuang & - \\
\hline & & Leaves & & - \\
\hline \multirow[t]{2}{*}{ Cucurbitaceae } & Melothria affinis & Whole plant & Belum & - \\
\hline & Trichosanthes wallichiana & Whole plant & Belum & - \\
\hline \multirow[t]{2}{*}{ Dilleniaceae } & Dillenia ovata & Leaves & Belum & + \\
\hline & & Bark & & - \\
\hline \multirow[t]{2}{*}{ Dipterocarpaceae } & Dipterocarpus sp. & Leaves & Belum & - \\
\hline & & Bark & & - \\
\hline \multirow[t]{2}{*}{ Dipterocarpaceae } & Shorea sp. & Leaves & Belum & ++ \\
\hline & & Bark & & - \\
\hline \multirow[t]{5}{*}{ Ebenaceae } & Diospyros buxifolia & Whole plant & Belum & - \\
\hline & Diospyros sp. & Leaves & Belum & - \\
\hline & & Bark & & - \\
\hline & & Seed & & - \\
\hline & & Fruit pulp & & ++ \\
\hline \multirow[t]{5}{*}{ Euphorbiaceae } & Baccaurea parviflora & Leaves & Belum & - \\
\hline & & Bark & & - \\
\hline & Baccaurea sp & Fruit & Belum & - \\
\hline & Mallotus sp. & Leaves & Belum & - \\
\hline & & Bark & & - \\
\hline
\end{tabular}


Table 1 Plant extracts screened for photo-cytotoxicity in HL60 cells at 20 ? $\mu ? \mathbf{g} / \mathbf{m l}$ (Continued)

\begin{tabular}{|c|c|c|c|c|}
\hline \multirow[t]{6}{*}{ Fabaceae } & Bauhinia sp. & Leaves & Belum & + \\
\hline & & Bark & & - \\
\hline & Bauhinia wrayi & Whole plant & Belum & - \\
\hline & Callerya atropurpurea & Fruit & Belum & - \\
\hline & Desmodium sp. & Whole plant & Belum & - \\
\hline & Mimosa sp. & Leaves & Belum & + \\
\hline Flacourtiaceae & Hydnocarpus sp. & Bark & Belum & - \\
\hline Gesneriaceae & Cyrtandra pendula & Leaves & Gunung Nuang & + \\
\hline \multirow[t]{3}{*}{ Hypoxidaceae } & Molineria latifolia & Fruit & Gunung Nuang & - \\
\hline & & Leaves & & - \\
\hline & & Root & & - \\
\hline \multirow[t]{2}{*}{ Icacinaceae } & Gonocaryum gracile & Leaves & Belum & + \\
\hline & & Bark & & - \\
\hline \multirow[t]{2}{*}{ Lasiocampoidea } & Barringtonia payensiana & Bark & Gunung Nuang & - \\
\hline & & Leaves & & - \\
\hline \multirow[t]{2}{*}{ Leeaceae } & Leea curtisii & Leaves & Belum & + \\
\hline & & Bark & & - \\
\hline Loganiaceae & Strychnos ignatii & Bark & Gunung Nuang & - \\
\hline Melastomataceae & Phyllagathis rotundifolia & Root & Gunung Nuang & - \\
\hline \multirow[t]{5}{*}{ Moraceae } & Ficus anulata & Whole plant & Belum & - \\
\hline & Ficus fulva & Fruit & Belum & - \\
\hline & Ficus laevis & Bark & Belum & - \\
\hline & & Bark & Gunung Nuang & - \\
\hline & & Leaves & & + \\
\hline Myrsinaceae & Ardisia minor & Leaves & Belum & + \\
\hline \multirow[t]{3}{*}{ Noctuoidea } & Corymborkis veratrifolia & Bark & Gunung Nuang & - \\
\hline & & Leaves & & - \\
\hline & Crinum asiaticum & Leaves & Belum & - \\
\hline Palmae & Rattan sp. & Whole plant & Belum & - \\
\hline \multirow[t]{4}{*}{ Piperaceae } & Piper caninum & Whole plant & Belum & + \\
\hline & Piper magnibaccum & Bark & Belum & - \\
\hline & Piper umbellatum & Leaves & Belum & - \\
\hline & & Bark & & - \\
\hline \multirow[t]{3}{*}{ Pyraloidea } & Mycetia malayana & Bark & Gunung Nuang & - \\
\hline & & Leaves & & - \\
\hline & & Root & & - \\
\hline \multirow[t]{12}{*}{ Rubiaceae } & Displospora wrayi & Bark & Gunung Nuang & - \\
\hline & & Fruit & & - \\
\hline & Ixora grandifolia & Leaves & Belum & + \\
\hline & & Bark & & - \\
\hline & Lasianthus bractescens & Bark & Belum & - \\
\hline & Lasianthus constrictus & Leaves & Belum & + \\
\hline & & Bark & & - \\
\hline & Lasianthus lowianus & Bark & Belum & - \\
\hline & & Fruit & & - \\
\hline & & Bark & Gunung Nuang & - \\
\hline & & Leaves & & - \\
\hline & & Root & & - \\
\hline \multirow[t]{2}{*}{ Rutaceae } & Luvunga scandens & Bark & Gunung Nuang & - \\
\hline & & Leaves & & + \\
\hline
\end{tabular}


Table 1 Plant extracts screened for photo-cytotoxicity in HL60 cells at 20 ? $\mu$ ?g/ml (Continued)

\begin{tabular}{|c|c|c|c|c|}
\hline \multirow[t]{2}{*}{ Selaginellaceae } & Selaginella intermedia & Bark & Gunung Nuang & - \\
\hline & & Leaves & & - \\
\hline \multirow[t]{2}{*}{ Solanaceae } & Solanum lasiocarpum & Leaves & Belum & + \\
\hline & & Bark & & - \\
\hline \multirow[t]{2}{*}{ Tiliaceae } & Microcos hirsuta & Bark & Belum & - \\
\hline & & Leaves & & - \\
\hline \multirow[t]{4}{*}{ Verbenaceae } & Clerodendron sp. & Leaves & Belum & + \\
\hline & & Bark & & - \\
\hline & Peronema canescens & Leaves & Belum & + \\
\hline & & Bark & & - \\
\hline \multirow[t]{2}{*}{ Vitaceae } & Cissus sp. & Leaves & Belum & + \\
\hline & & Bark & & - \\
\hline Zingiberaceae & Boesenbergia sp. & Whole plant & Belum & - \\
\hline
\end{tabular}

* +: photo-cytotoxic only, ++: cytotoxic, -: no activity

viable when exposed to light and if the \% cell viability of the culture with the sample in the dark is more than double the \% cell viability in the presence of light [5-8]. Following these criteria, 27 of the extracts were identified as photo-cytotoxic. Three samples from Garcinia malaccensis (root), Shorea sp. (leaves) and Disopyros sp. (fruit pulp) showed cytotoxicity even when unirradiated ( $<50 \%$ cell viability in the unirradiated experiment) and therefore were not investigated further in this study. The 27 photo-cytotoxic extracts were from different plant species except for Anaxagorea javanica which contributed two extracts from its bark and leaves. Other than the bark extract from A. javanica and the whole plant extract from Piper caninum, the remaining 25 photo-cytotoxic extracts were all prepared from the leaves. The photo-cytotoxic extract from the leaves of $P$. ophthalmicus was subsequently subjected to bioassay guided fractionation using standard chromatography methods to identify the photo-cytotoxic constituents.

\section{Phaeanthus ophthalmicus as a source of photosensitisers}

Phaeanthus ophthalmicus is a small shrub commonly found in shady forest [9]. No literature related to its phytochemical or ethnopharmaceutical uses have been reported for this species. Of relevance to this study, this species has not been studied for photosensitizing activities also. As a genus, Phaeanthus belongs to the family Annonaceae (blumea) which is the largest family of the magnolia order (Magnoliales). The Annonaceae family consists of trees, shrubs, and woody climbers found mainly in the tropics, although a few species extend into temperate regions [10]. Even though the Annonaceae family elaborates a broad array of secondary metabolites [11], the genus Phaeanthus has not been studied extensively and only a small amount of literature related to its phytochemical or ethnopharmaceutical uses have been reported. Among the phytochemical studies on the genus Phaeanthus including $P$. ebracteolatus, $P$. vietnamensis and $P$. crassipetalus, have reported compounds such as phaeanthine, phaeantharine, argentinine, limacine, $\mathrm{O}, \mathrm{O}^{\prime}$ - dimethylgrisabine and 7-O-methylgrisabine $[12,13]$, and importantly none of these compound classes have been used as photosensitisers for photodynamic therapy.

\section{Fractionation of the active extract and isolation of compound 1}

Thin layer chromatography (TLC) profiles of active fractions 2 - 17 (hexane: ethyl acetate, 7:3, v/v) from the leave extract of $P$. ophthalmicus were obtained together with our in-house standard photosensitisers. Pheophorbide- $a$, pheophorbide- $a$ methyl ester, $13^{2}$-hydroxypheophorbide- $a$ methyl ester, pheophytin- $a$ and $15^{1}$ hydroxypurpurin 7-lactone dimethyl ester were identified as present in fractions 2-16 according to TLC, and would explain the photo-cytotoxicity observed in these fractions. The presence of the known compounds in the active fractions was further confirmed by co-injection of the standard photosensitisers with fractions 2-16 in HPLC analytical runs. Furthermore, as none of the standard photosensitisers co-eluted with constituents in fraction 17, this fraction may contain new photosensitisers and was selected for further analysis and purification using HPLC.

A yellowish green compound (1; Figure 1) was isolated $(<1 \mathrm{mg}$ ) from HPLC purification of fraction 17. The HRMS analysis of the isolated compound gave the observed $[\mathrm{M}+1]$ peak at $m / z 639.2495$ (calculated [M $+1]: m / z$ 639.2455, $6.3 \mathrm{ppm}$ ), consistent with molecular formula of $\mathrm{C}_{35} \mathrm{H}_{35} \mathrm{~N}_{4} \mathrm{O}_{8}$. Compound 1 has additional 14 a.m.u. compared to $15^{1}$-hydroxypurpurin-7-lactone methyl ester (2) [14], in line with the proposed 

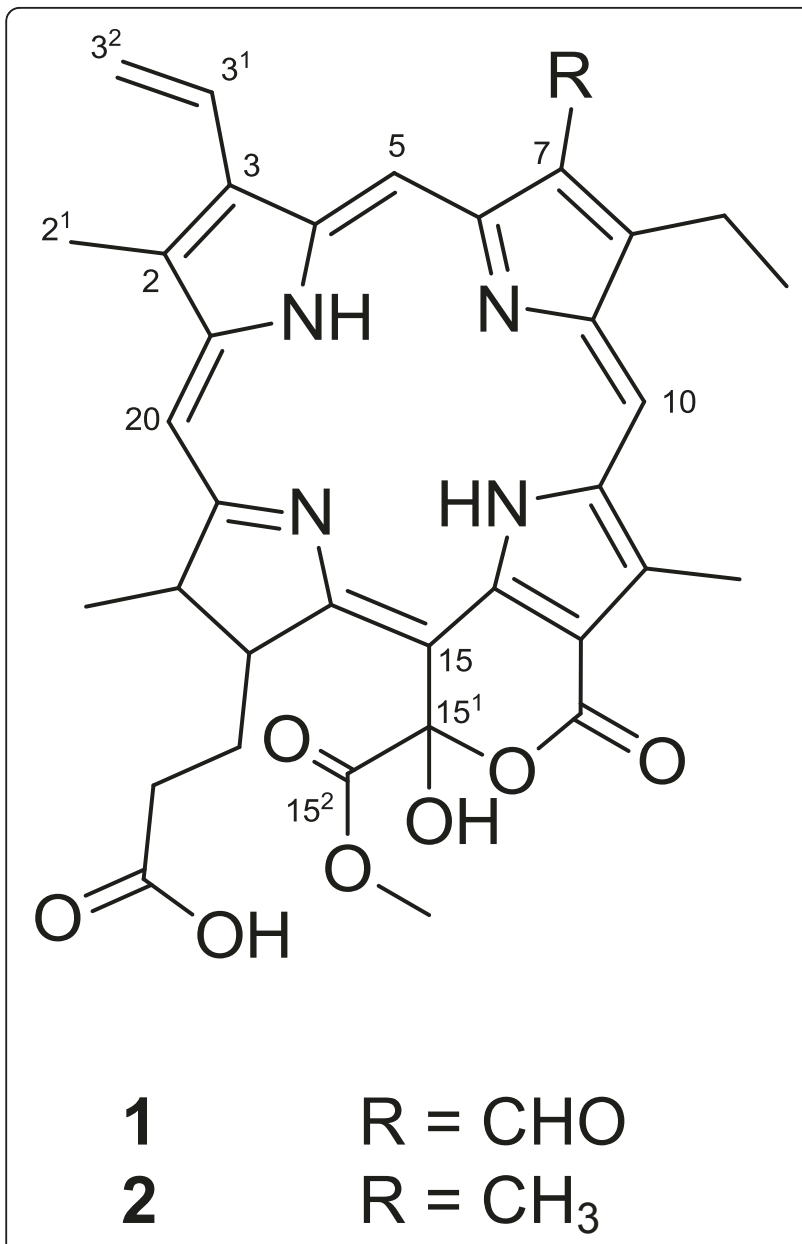

Figure 1 Chemical structure of compounds 1 and 2 .

replacement of the methyl group at C-7 in 2 with an aldehyde in $\mathbf{1}$. In addition, the mass fragments observable at $m / z 621, m / z 579$ and $m / z 552$ were in accordance with the loss of $\mathrm{H}_{2} \mathrm{O}$ (18 a.m.u.), $\mathrm{C}_{2} \mathrm{H}_{4} \mathrm{O}_{2}$ (60 a.m. u.) and $\mathrm{C}_{3} \mathrm{H}_{3} \mathrm{O}_{3}$ (87 a.m.u.) from the molecular ion. These mass losses of 60 a.m.u. and 87 a.m.u. were similar to those observed by Walker et al [15] for $15^{1}$-methoxylactonechlorophyll- $a$, thus suggesting that compound 1 also contained a lactone ring structure. The UV-vis absorption spectrum of 1 showed $\lambda_{\max }$ at $226 \mathrm{~nm}, 427$ $\mathrm{nm}$ and $651 \mathrm{~nm}$, characteristic of a pheophorbide- $b$-type structure [16]. The ${ }^{1} \mathrm{H}$ NMR spectrum of 1 revealed resonances that are typical of pheophobide- $b$, including a singlet proton signal at $\delta 11.21$ for the aldehyde at C7, three singlet signals assignable to $\mathrm{H}-10, \mathrm{H}-5$ and $\mathrm{H}-$ 20 at $\delta 10.53,9.91$ and $8.66 \mathrm{ppm}$ respectively, a vinyl group at C-3 with signals at $\delta 8.05(\mathrm{dd}, J=11.4,17.4$ $H z), \delta 6.45(\mathrm{~d}, J=17.4 \mathrm{~Hz})$ and $\delta 6.26(\mathrm{~d}, J=11.4 \mathrm{~Hz})$, and signals for the two methyl groups which are directly connected to the conjugated ring system at $\delta 3.79$ ( $\mathrm{H}-$ $\left.12^{1}\right)$ and $3.43\left(\mathrm{H}-2^{1}\right)$. Due to the presence of the electron-withdrawing aldehyde moiety at the position of C-7, the observed chemical shifts of the protons surrounding the tetrapyrrole skeleton were more deshielded compared to the reported literature values for pheophorbide- $a$ type compounds [17]. On the basis of these evidence, compound $\mathbf{1}$ was identified as 7-formyl$15^{1}$-hydroxypurpurin-7-lactone methyl ester.

Compound 1 has not been reported to be a natural product from plants and no spectroscopic data for the exact structure is available in the literature. However, compound 2 (Figure 1) which has a C7 methyl group is a chlorophyll- $a$ equivalent of compound $\mathbf{1}$, and has been cited to be found in an oxidised leave extract [14]. Since derivatives such as compound $\mathbf{2}$ with an exocyclic lactone ring can be prepared by oxidation of the parent pentacyclic chlorophyll- $a$ structure and have been identified in plant extracts [6], compound $\mathbf{1}$ is probably also derivable from chlorophyll- $b$ which is ubiquitously present in green leaves together with chlorophyll- $a$.

\section{Conclusion}

In this study, 128 crude extracts from 64 Malaysian terrestrial plants collected from the Royal Belum Forest Reserve and Gunung Nuang Langat Reserve Forest were screened for photo-activity in a cell-based assay. Twenty-seven of these extracts showed photo-cytotoxicity at $20 \mu \mathrm{g} / \mathrm{mL}$ and when exposed to $9.6 \mathrm{~J} / \mathrm{cm}^{2}$ of a broad spectrum light. One of the photo-cytotoxic extracts from the leaves of Phaeanthus ophthalmicus was further investigated through bioassay-guided fractionation of the extract to yield seventeen fractions. Based on TLC and analytical HPLC analysis with known standard compounds in our organisation, five known photosensitisers were successfully identified in fractions 2-16 as pheophorbide- $a$, pheophorbide- $a$ methyl ester, $13^{2}$ hydroxylpheophorbide- $a$ methyl ester, pheophytin- $a$ and $15^{1}$-hydroxypurpurin 7 -lactone dimethyl ester. The photo-cytotoxic fraction 17 consisted of a new compound which was isolated and elucidated to be 7 -formyl-15 ${ }^{1}$-hydroxypurpurin-7-lactone methyl ester based on spectroscopic data. This is the first effort to study the photosensitisers present in P. ophtalmicus and further characterisation of compound $\mathbf{1}$ as a photosensitiser for photodynamic therapy is underway.

\section{Experimental}

\section{General Instrumentation}

Light doses were measured using Nova-Oriel power meter. The 96-well microplates were read using ThermoLabsystems OpsysMR microplate spectrometer. Columns for chromatography were packed using Silica gel $\mathrm{F}_{254}$ Merck Kieselgel 60 (70-230 mesh). High Performance Liquid Chromatography (HPLC) analysis of extracts and fractions was performed using Shimadzu 
system equipped with LC-10AT VP pumps, SPDM10AVP photo-diode array (PDA) detector while purification of compound $\mathbf{1}$ was carried out using Waters HPLC system equipped with 2998 PDA detector, Waters 600 Controller and Delta 600 Pumps. Merck Chromolith ${ }^{\circledR}$ monolithic RP-18e, $4.6 \times 100 \mathrm{~mm}$ HPLC column was used. The High Resolution Mass Spectrometry (HRMS) of the isolated compound was performed using Acquity ${ }^{\mathrm{TM}}$ Ultra Performance Liquid Chromatography (UPLC)-PDA system coupled to Synapt High Definition Mass Spectrometry (HDMS) Quadrupole-orthogonal acceleration Time-of-Flight (oaTOF) detector (Waters Corperation, USA) equipped with an Electrospray Ion source (ESI). The Nuclear Magnetic Resonance (NMR) analysis was done using Bruker Avance III $600 \mathrm{MHz}$ FT-NMR spectrometer with CryoProbe.

\section{Chemicals}

All chemicals and solvents used were of analytical grade. Pheophorbide- $a$ standard for photo-cytotoxicity assay was purchased from Frontier Scientific Inc, USA.

\section{Plant materials}

Plant materials were collected randomly along existing trails from Royal Belum Forest Reserve in the State of Perak and Gunung Nuang, Langat Forest Reserve in the State of Selangor on two separate expeditions consisting of members of the research team, a taxonomist from Universiti Putra Malaysia and the forest rangers in July 2007. The expedition to Royal Belum Forest Reserve was carried out at the northern region near the border of Thailand, along the Sungai Kejar river and the Rafflesia site which are lowlands and hill dipterocarp forests. Expedition to Gunung Nuang at the Langat Forest Reserve was carried out at $221.1 \mathrm{~m}$ above sea level along the walking trail near the running water pipeline. Taxonomic identification was performed by Shamsul Khamis from Institute of BioScience, Universiti Putra Malaysia and voucher of the specimens were recorded and deposited in the Applied Chemistry Laboratory Herbarium, Sime Darby Technology Centre, Malaysia.

\section{Preparation of plant extracts}

The plant materials were separated according to plant parts, washed and ground. The finely ground plant materials were extracted with ethanol for three days, and extraction of the same materials was repeat two more times. The combined ethanolic extracts were dried in vacuo and kept at $0^{\circ} \mathrm{C}$ before use.

Cell culture and determination of photo-cytotoxicity by MTT Assay

HL60 promyelocytic leukemia cells were obtained from ATCC and cultured in RPMI 1640 medium supplemented with $1 \%{ }^{\mathrm{v}} / \mathrm{v}$ glutamine and $10 \%$ foetal bovine serum (FBS) (Gibco). The assay described by Mosmann [18] was adapted to the measurement of cell viability with some modification. Briefly, test compounds were prepared as stock solutions of $20 \mathrm{mg} / \mathrm{ml}$ in DMSO and diluted accordingly in phenol red free culture medium supplemented with 5\% FBS before use. In a 96-well plate, extracts at a concentration of $20 \mu \mathrm{g} / \mathrm{ml}$ were tested against 15000 of HL60 cells per well for two hours at 37 ${ }^{\circ} \mathrm{C}$ in $5 \% \mathrm{CO}_{2}$. All test compounds were assayed in four replicate wells $(n=4)$. The plates were then irradiated with a $300 \mathrm{~W}$ broad spectrum tungsten halogen lamp, with the infra-red radiation being removed by means of a $10 \mathrm{~cm}$ water column. Cell cultures were irradiated at 10.5 $\mathrm{mW} / \mathrm{cm}^{2}$ light energy for a duration of $10 \mathrm{~min}$, which corresponds to a light dose of $9.6 \mathrm{~J} / \mathrm{cm}^{2}$. A duplicate experiment containing cells incubated with either the same samples but without light irradiation was conducted to serve as un-irradiated control. Then, the cells in both sets of experiments were incubated for a further 24 hours. Cell viability was then determined with the MTT (3-(4,5-dimethylthiazol-2-yl)-2,5-diphenyl-2 $H$-tetrazolium hydrobromide) assay. MTT (Fluka) was diluted to $5 \mathrm{mg} / \mathrm{ml}$ in phosphate-buffered saline (PBS) just prior to use. A volume of $15 \mu \mathrm{l}$ of this solution was added to all the wells. The plate was incubated for another 4 hours at $37{ }^{\circ} \mathrm{C}$. Then, $70 \mu \mathrm{l}$ of the supernatant was removed, and $100 \mu \mathrm{l}$ of DMSO was added to dissolve the formazan crystals. Their absorbance was recorded on a microplate spectrometer at $570 \mathrm{~nm}$, and the percentage of cell death was calculated relative to untreated cells.

\section{Fractionation of photo-cytotoxic extract from Phaeanthus} ophthalmicus

Approximately $50 \mathrm{~g}$ of the ethanolic crude extract from the leaves of $P$. ophthalmicus was fractionated by liquidliquid partitioning into petroleum ether, dichloromethane, ethyl acetate and water fractions to yield 12.8 $\mathrm{g}, 3.6 \mathrm{~g}, 8.1 \mathrm{~g}$ and $26.3 \mathrm{~g}$ of dried fractions respectively. All of the fractions were assayed for photo-cytotoxicity and the petroleum ether fraction was found to be active in the bio-assay and was further fractionated using standard silica gel eluting with solvent in increasing polarity (hexane, ethyl acetate and methanol). The fractions were collected based on visual bands, dried in vacuo and tested for photo-cytotoxicity. A total of 17 fractions were collected and fractions 2 to 17 showed photo-cytotoxicity at a concentration of $10 \mu \mathrm{g} / \mathrm{mL}$.

\section{Isolation of compound 1 from photo-cytotoxic fraction}

Fraction 17 was subjected for further isolation and purification using Waters HPLC system with 2998 PDA detector; Waters 600 Controller and Delta 600 Pumps, eluted at a constant rate of $1 \mathrm{ml} / \mathrm{min}$, in a gradient of $40 \%$ to $80 \%$ of acetonitril (0-5 mins), from $80 \%$ to $100 \%$ of acetonitril (5-15 mins) and hold at 100\% acetonitril for 5 mins, using Merck Chromolith ${ }^{\circledR}$ RP-18e, $4.6 \times 100$ $\mathrm{mm}$ column. The peak which was eluted at $R_{t} 1.81 \mathrm{~min}$ and which had UV-vis absorption maxima at $226 \mathrm{~nm}$, $427 \mathrm{~nm}$ and $651 \mathrm{~nm}$ was collected as compound $\mathbf{1}$. 


\section{Acknowledgements}

CARIF is a non-profit research organisation. We thank the sponsors of CARIF for partly funding this work.

\section{Author details}

${ }^{1}$ Cancer Research Initiatives Foundation (CARIF), Sime Darby Medical Centre,1, Jalan SS12/1A, 47500 Subang Jaya, Selangor Darul Ehsan, Malaysia. ${ }^{2}$ Sime Darby Technology Centre, 2 Jalan Tandang, 46050 Petaling Jaya, Selangor Darul Ehsan, Malaysia.

\section{Authors' contributions}

CYO performed the photo-cytotoxicity testing of 128 extracts. PJT was involved in the isolation, purification and identification of compound $\mathbf{1}$. AD and HMY participated in the sample collection and the preparation of the plant extracts. HBL and BKN participated in the study design and coordination of study. HBL, PJT and CYO contributed to the drafting of the manuscript. All authors have read and approved the final manuscript.

\section{Competing interests}

The authors declare that they have no competing interests.

Received: 18 February 2011 Accepted: 20 June 2011

Published: 20 June 2011

\section{References}

1. Hashim R, Amran MA, Yusoff MM, Siarap K, Mohamed R, Hussein A, Wong CJ: The Environmental non-governmental organizations (ENGOs) in Malaysia Northern Region: Their roles in protecting water resources. INGOJ 2010, 5:167-170.

2. Oon H: Malaysia London: New Holland Publishers; 2008.

3. Kono I, Nishigaki M, Komatsu M: Groundwater Engineering - Recent Advances Netherlands: Swets \& Zeitlinger Publishers; 2003.

4. Castano AP, Demidova TN, Hamblin MR: Mechanisms in photodynamic therapy: part one - photosensitizers, photochemistry and cellular localization. Photodiag Photodyn Ther 2004, 1:279-293.

5. Kamal N, Sabaratnam V, Abdullah N, Ho ASH, Teo SH, Lee HB: Lightactivated cytotoxic compounds from Malaysian microorganisms for photodynamic therapy of cancer. Antonie van Leeuwenhoek 2009, 95:179-188.

6. Chee CF, Lee HB, Ong HC, Ho ASH: Photocytotoxic Pheophorbide-related compounds from Aglaonema simplex. Chem Biodiversity 2005, 2:1648-1655.

7. Ong CY, Ling SK, Ali RM, Chee CF, Samah ZA, Ho ASH, Teo SH, Lee HB: Systematic analysis of in vitro photo-cytotoxic activity in extracts from terrestrial plants in Peninsula Malaysia for photodynamic therapy. $J$ Photochem Photobiol B 2009, 96:216-222.

8. Kamarulzaman FA, Shaari K, Ho ASH, Lajis NH, Teo SH, Lee HB: Derivatives of pheophorbide-a and pheophorbide-b from photocytotoxic Piper penangense extract. Chem Biodivers 2011, 8:494-502.

9. Keng H, Keng RSLK: The Concise Flora of Singapore: Gymnosperms and Dicotyledons Singapore: NUS Press; 1990.

10. Britannica Online Encyclopedia. 2009 [http://www.britannica.com]

11. Wiart C: Medicinal Plants of Asia and the Pacific Boca Raton: CRC Press; 2006

12. Johns SR, Lamberton JA, Sioumis AA: Alkaloids of a Phaeanthus species from New Guinea, Isolation of Phaeanthine and Limacine. Aust J Chem 1968, 21:1387-1388.

13. López-Martín J, Anam EM, Boira H, Sanz MJ, Blázquez MA: Chromone and Phenenthrene Alkaloids from Dennettia tripetala. Chem Pharm Bull 2002 50:1613-1615.

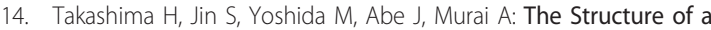
metabolite from leaves of Winter Wheat inoculated with $\mathrm{H}_{2} \mathrm{O}_{2}$. Chem Lett 1995, 24:1015-1016.

15. Walker JS, Jie C, Keely BJ: Identification of diastereomeric chlorophyll allomers by atmospheric pressure chemical ionization liquid chromatography/tandem mass spectrometry. Rapid Commun Mass Spectrom 2003, 17:1125-1131.

16. Kobayahi M, Akiyama M, Kano H, Kise H: Spectroscopy and Structure Determination. In Chlorophylls and Bacteriochlorophylls: Biochemistry, Biophysics, Functions and Applications. Advances in Photosynthesis and Respiration. Volume 25. Edited by: Grimm B, Porra RJ, Rudiger W, Scheer H. Dordrecht: Springer; 2006:79-94.
17. Cheng HH, Wang HK, Ito J, Bastow KF, Tachibana Y, Nakanishi Y, Xu ZH, Luo TY, Lee KH: Cytotoxic Pheophorbide-Related Compounds from Clerodendrum calamistosum and C. cyrtophyllum. J Nat Prod 2001, 64:915-919.

18. Mosmann T: Rapid colorimetric assay for cellular growth and survival: application to proliferation and cytotoxicity assays. J Immunol Methods 1983, 65:55-63.

doi:10.1186/1752-153X-5-32

Cite this article as: Tan et al:: Cyclic Tetrapyrrolic Photosensitisers from the leaves of Phaeanthus ophthalmicus. Chemistry Central Journal 2011 5:32.

\section{Publish with ChemistryCentral and every scientist can read your work free of charge \\ "Open access provides opportunities to our colleagues in other parts of the globe, by allowing anyone to view the content free of charge." W. Jeffery Hurst, The Hershey Company.}

- available free of charge to the entire scientific community

- peer reviewed and published immediately upon acceptance

- cited in PubMed and archived on PubMed Central

- yours - you keep the copyright

Submit your manuscript here:

http://www.chemistrycentral.com/manuscript/<smiles>c1ccccc1</smiles>

ChemistryCentral 